\title{
Impact of fertilization on the mineral nutrition and yield of Salix triandra $x$ Salix viminalis and Robinia pseudoacacia L. bioenergy crops
}

\author{
${ }^{1}$ László Simon, ${ }^{1}$ Béla SzABó, ${ }^{1}$ György Vincze, ${ }^{1}$ Miklós Szabó, ${ }^{2}$ József KonCz \\ ${ }^{1}$ Department of Agricultural Sciences and Environmental Management, Institute of \\ Engineering and Agricultural Sciences, University of Nyíregyháza, Nyíregyháza, \\ Hungary; \\ ${ }^{2}$ Institute for Soil Sciences and Agricultural Chemistry, Centre for Agricultural \\ Research, Hungarian Academy of Sciences, Budapest, Hungary
}

\begin{abstract}
Willow was cultivated as an energy crop in a field experiment. The brown forest soil was treated with an inorganic fertilizer (ammonium nitrate-AN: $100 \mathrm{~kg}$ $h a^{-1}$ ) or with various organic or mineral soil amendments (municipal biocompost-MBC: $20 t h a^{-1}$; municipal sewage sludge compost-MSSC: $15 t h a^{-1}$; rhyolite tuff-RT: $30 t h a^{-1}$; willow ash-WA: $600 \mathrm{~kg} \mathrm{ha}^{-1}$ ), or their combinations $(\mathrm{AN}+\mathrm{MBC} ; \mathrm{AN}+\mathrm{RT} ; \mathrm{AN}+\mathrm{WA}, \mathrm{MSSC}+\mathrm{WA})$ in four replications. Nineteen months after the soil treatments the macroelement-rich amendments (MBC, MSSC) enhanced the harvested fresh shoot yield most significantly (up to $41 \%$ as compared to the untreated control), and also the shoot diameter and shoot height of the willow plants. Most of the treatments enhanced the uptake of $\mathrm{N}(9.8-23.5 \%)$ and $\mathrm{K}$ in willow leaves, but the concentrations of $\mathrm{P}, \mathrm{Mg}, \mathrm{Ca}, \mathrm{Fe}$ and $\mathrm{Zn}$ in the leaves were reduced. The toxic element $(\mathrm{As}, \mathrm{Cd}, \mathrm{Pb})$ accumulation of willow shoots was negligible.

In a 4-year field experiment the effects of the mineral fertilizers $\mathrm{AN}$ and $\mathrm{AN}+$ calcium-magnesium carbonate $(\mathrm{CMC})$ were studied on the mineral nutrition of the leaves and wood yield of black locust trees cultivated as an energy crop. The brown forest soil was treated with $300 \mathrm{~kg} \mathrm{~h} a^{-1}$ annual doses of these fertilizers as top-dressing in June 2009, May 2010 and May 2011. Both fertilizers caused a three to four times increase in the nitrate content of the upper soil soon after their application in June. By the end of the vegetation period (in December) the nitrate concentration in the soil was similar to that in the control plots. The nitrogen content of the leaf stalks (petioles) and leaves, however, was only slightly higher in the treated plots. As a trend, fertilization increased the phosphorus and reduced the calcium uptake in the leaf stalks and leaves, while the magnesium content was not influenced. In March 2012, when the whole trees were harvested, $22 \%$ or $28 \%$ higher aboveground fresh shoot weight was detected in the AN or AN+CMC treatments than in the control.
\end{abstract}

Postal address: LÁSZLó SIMON, University of Nyíregyháza, Institute of Engineering and Agricultural Sciences, Department of Agricultural Sciences and Environmental Management, H-4400 Nyíregyháza Sóstói út 31/b., Hungary.

E-mail: simon.laszlo@nye.hu 
Keywords: willow, black locust, fertilization, elemental composition of leaves, shoot yield

\section{Introduction}

Among the population of rural areas in Hungary there is a long tradition of utilizing woody (arboreal) biomass for heat generation. The cultivation of traditional food and feed plants is concentrated on areas with more favourable growth conditions, while on approximately 0.5 million hectares with unfavourable agroecological conditions there is a prospect for alternative land use, e.g. the growing of energy crops. The cultivation of energy crops and the utilization of the biomass in small 1-2 MW municipal district-heating power plants could reduce both unemployment and the fossil fuel (natural gas) dependence of underdeveloped rural areas in Hungary (BLASKÓ, 2008).

Besides Populus species (RÉDEI \& KESERÜ, 2008), the two most suitable woody plant species for the establishment of short rotation coppice (SRC) bioenergy plantations in Hungary are willow (Salix) species (GYURICZA, 2011) and black locust (Robinia pseudoacacia L.) (RÉDEI \& VEPERDI, 2009; NICOLESCU et al., 2018). Willow is a more appropriate crop on low-lying areas periodically covered with water, while black locust could be more efficient on loose (dry) sandy soils.

The harvestable fresh shoot biomass of various willow (Salix) species may be as much as 20 or 25 tons per hectare (or 10-12 tons of dry matter) annually (SMART \& CAMERON, 2012). The harvestable and combustible aboveground biomass of willow species can be enhanced by the soil application of various inorganic (e.g. artificial fertilizers, wood ash) or organic manures and additives, including biowastes (e.g. sewage sludge) (DIMITRIOU et al., 2006; GYURICZA et al., 2008; GYURICZA, 2011; PARK et al., 2005; SMART \& CAMERON, 2012). Increased growth is usually observed in willow stands following fertilization, but in some cases the effect is limited. This variation could be explained by the actual nutrient status of the soil, or by the type and availability of nutrients in the fertilizer. The nitrogen status of the soil is regarded as crucial (SEVEL et al., 2014a, b).

As a member of the Fabaceae family, black locust is able to fix nitrogen through a root symbiont Rhizobium forming perennial nodules. It can also tolerate stress and sequester carbon while generating biomass yields of up to $14 t h a^{-1}$ annually (STRAKER et al., 2015). Relatively few data are available on the stimulation of black locust growth with fertilizers in SRC systems. In a Hungarian long-term fertilization trial black locust was grown in a soil formerly treated regularly with high doses of NPK fertilizers and thereafter with lime. NPK fertilization improved the wood volume and yield quality despite the poor fertility of the soil. Liming had a significant effect on the uptake of nutrients, and on the growth parameters studied (HARTA et al., 2016). Due to its ability to grow on marginal sites, black locust has been widely planted on post-mining areas (KANZLER et al., 2015; BRINKS et al., 2011). PLASS (1972) found that ammonium nitrate and various phosphate fertilizers stimulated the vertical growth of black locust trees on extremely acid surface-mine spoils. Phosphate fertilization greatly 
increased the total dry weight yield of young black locust saplings, while in older plants no yield increase was observed, but the $\mathrm{P}$ concentration was enhanced in the leaves (KANZLER et al., 2015). A single application of granular fertilizer with $37 \mathrm{~kg}$ $\mathrm{N}, 30 \mathrm{~kg} \mathrm{P}$ and $16 \mathrm{~kg} \mathrm{~K}^{-1}$ significantly enhanced the stem biomass, mean diameter and height of 1-year-old black locust saplings grown on reclaimed surface mine lands (BRINKS et al., 2011).

Since most of the SRC plantations in Hungary were established over the past fifteen years, few data are available on how the application of fertilizers or amendments affects the mineral nutrition, chemical composition and yield of bioenergy crops. The assumption was that the mineral nutrients present in the chemical fertilizers (ammonium nitrate, ammonium nitrate with calciummagnesium carbonate), biowastes (municipal biocompost, municipal sewage sludge compost) and mineral amendments (rhyolite tuff, willow ash) tested would have different effects on the uptake or accumulation of macro, micro or toxic elements in the leaves, which in turn would have a stimulating or inhibitory effect on harvestable wood yields. The impact of the various detrimental effects of ammonium nitrate was compared to other amendments. A further question was whether any toxic metals from the biowastes or wood ash would be accumulated in the willow leaves. In spite of its relatively high rate of gaseous nitrogen fixation, black locust was expected to respond to the soil application of nitrogen fertilizers with a yield increase. The aim of the research was to find answers to these questions.

\section{Materials and Methods}

\section{Experiment on willow}

A small-plot field experiment was set up with willow (Salix triandra $x$ Salix viminalis cv. Inger) in April 2011 in the experimental field of the Research Institute of Nyíregyháza, Centre of Agricultural Sciences, University of Debrecen (located in Nyíregyháza) with 10 treatments in 4 replications. In each $27 \mathrm{~m}^{2}$ plots 40 willow plants were grown. The uncontaminated brown forest soil (loamy sand texture, $\mathrm{K}\left({ }_{\mathrm{A}}\right.$ ) 31; CEC 10.4 cmolc kg ${ }^{-1} ; \mathrm{pH}_{\mathrm{H} 2 \mathrm{O}} 8.10 ; \mathrm{pH}_{\mathrm{KCl}} 7.52 ; \mathrm{CaCO}_{3} 4.80 \mathrm{~m} / \mathrm{m} \%$; total salt content $<0.02 \mathrm{~m} / \mathrm{m} \%$; humus $1.51 \mathrm{~m} / \mathrm{m} \%$; CEC $10.4 \mathrm{cmolc} / \mathrm{kg}$; P-713, K-5653, $\mathrm{Ca}-21773, \mathrm{Mg}-5471, \mathrm{Cu}-12.7, \mathrm{Mn}-653, \mathrm{Zn}-44.3, \mathrm{As}-38.3, \mathrm{Cd}-0.11, \mathrm{~Pb}-13.6 \mathrm{mg}$ $\mathrm{kg}^{-1}$ in $\mathrm{HNO}_{3}-\mathrm{H}_{2} \mathrm{O}_{2}$ extract) was treated in early June 2011 as follows:

1. Control (untreated);

2. Ammonium nitrate $(34 \% \mathrm{~N})-\mathrm{AN}: 100 \mathrm{~kg} \mathrm{ha}^{-1}$ dry weight, applied as topdressing;

3. Municipal biocompost - MBC: $20 t h a^{-1}$ wet weight with $75-76 \%$ dry matter;

4. Municipal sewage sludge compost - MSSC: $15 t h a^{-1}$ wet weight with 48$56 \%$ dry matter;

5. Rhyolite tuff-RT: $30 t h a^{-1}$ wet weight with $18 \%$ moisture content; 
6. Willow ash - WA: $600 \mathrm{~kg} \mathrm{ha}^{-1}$ dry weight (produced at the College of Nyíregyháza by burning willow shoots);

7. $100 \mathrm{~kg} \mathrm{ha}^{-1} \mathrm{AN}+20 \mathrm{tha^{-1 }} \mathrm{MBC}$;

8. $100 \mathrm{~kg} \mathrm{ha}^{-1} \mathrm{AN}+30 \mathrm{th} \mathrm{a}^{-1} \mathrm{RT}$;

9. $100 \mathrm{~kg} \mathrm{ha}^{-1} \mathrm{AN}+600 \mathrm{~kg} \mathrm{ha}^{-1} \mathrm{WA}$;

10. $15 \mathrm{tha}^{-1} \mathrm{MSSC}+600 \mathrm{~kg} \mathrm{ha}^{-1} \mathrm{WA}$.

The plots were treated for the second time with $100 \mathrm{~kg} \mathrm{ha}^{-1} \mathrm{AN}$ (as topdressing) in June 2012, while the other soil treatments were not repeated in 2012.

The methods used to analyse the basic physical and chemical properties (including plant-available nutrient concentrations) of brown forest soil, MBC, MSSC, RT and WA were described in previous studies (SIMON et al., 2011a, SIMON et al., 2013a, b; 2016; SzABÓ et al., 2011, 2012) and the results of the analysis are published in a parallel paper in this volume (SIMON et al., 2018).

Willow leaves were sampled from the $30-60 \mathrm{~cm}$ uppermost section of shoots from twenty plants per plot in 3 replications in September 2011 (SIMON et al., 2016).

The diameter of the willow shoots was measured at heights of $50 \mathrm{~cm}$ and 100 $\mathrm{cm}$ with callipers in December 2012. Measurements were made on 20 plants/plot in 4 replications ( 80 plants/treatment). At the same time 10 of the 40 plants in each plot were chosen to count the number of shoots in a bush. Counts were made on 10 plants/plot in 4 replications (40 plants/treatment).

All the shoots were harvested in January 2013. The shoots in every 4 rows of an experimental plot were weighed on a portable scale in 4 replications. The maximum shoot length was measured in the bunch of plants harvested in a given row in 3 replications (4 rows $\times 3$ measurements/plot $x 4$ treatment replications) in January 2013.

\section{Experiment on black locust}

The black locust plantation (Robinia pseudoacacia L., unidentified cultivar selected for SRC) was established in spring 2008, when one-year-old saplings were planted in brown forest soil in the experimental field of the Research Institute of Nyíregyháza, Centre of Agricultural Sciences, University of Debrecen (located in Nyíregyháza). In each $42 \mathrm{~m}^{2}$ plot 35 trees were grown. The basic properties of the untreated brown forest soil were as follows: loamy sand texture, $\mathrm{K}\left({ }_{\mathrm{A}}\right) 30, \mathrm{pH}_{\mathrm{H} 2 \mathrm{O}}$ $8.13, \mathrm{pH}_{\mathrm{KCl}} 7.50$, humus $1.31 \mathrm{~m} / \mathrm{m} \%$, total salt content $<0.02 \mathrm{~m} / \mathrm{m} \%, \mathrm{CaCO}_{3} 3.78$ $\mathrm{m} / \mathrm{m} \%, \sum \mathrm{N} 0.08 \mathrm{~m} / \mathrm{m} \%, \mathrm{NH}_{4}-\mathrm{N} 4.61 \mathrm{~m} / \mathrm{m} \%, \mathrm{NO}_{3}-\mathrm{N} 4.37 \mathrm{~m} / \mathrm{m} \%$, AL- $\mathrm{K}_{2} \mathrm{O} 150 \mathrm{mg}$ $\mathrm{kg}^{-1}, \mathrm{AL}^{-} \mathrm{P}_{2} \mathrm{O}_{5} 364 \mathrm{mg} \mathrm{kg}^{-1}$ (SIMON et al, 2011a,b).

The experiment was set up with three treatments in two replications. The soil was treated in June 2009, May 2010, and May 2011 as follows:

1. Control (untreated);

2. Ammonium nitrate $(34 \% \mathrm{~N})-\mathrm{AN}: 300 \mathrm{~kg} \mathrm{ha}^{-1}(102 \mathrm{~kg} \mathrm{~N} / \mathrm{ha})$ dry weight, applied as top-dressing; 
3. Ammonium nitrate with calcium magnesium carbonate $(27 \% \mathrm{~N} ; 7 \% \mathrm{CaO}$, 5\% MgO; ammonium nitrate) - AN-CMC: $300 \mathrm{~kg} \mathrm{ha}^{-1}$ (81 kg N/ha, $21 \mathrm{~kg}$ $\mathrm{CaO} / \mathrm{ha}, 15 \mathrm{~kg} \mathrm{MgO} / \mathrm{ha}$ ) dry weight, applied as top-dressing.

Soil samples were taken in June 2009 and December 2009 from a depth of 0$25 \mathrm{~cm}$ with rod augers. Two parallel samples were taken from each treatment, combining 30 randomly taken subsamples per plot, and resulting in $1.5 \mathrm{~kg}$ of total soil sample weights per plot (SIMON et al., 2011b).

Black locust leaves were sampled from thirty trees per plot in two replications in October 2011. At least two folioles (located in the uppermost section of the branches) were collected from each tree at a height of 2-2.5 m (SIMON et al., 2011b). The folioles were divided into leaf stalks (petioles) and leaves before analysis.

In March 2012 the 5-year-old black locust trees were harvested to evaluate the effects of three times repeated treatments with AN or AN-CMC on the yield parameters. Thirty whole 5 -year-old trees per plot ( 60 plants per treatment) were cut down to measure their maximum length and total defoliated fresh shoot weight.

\section{Soil and plant analysis}

Soil samples were air-dried and sieved, after which their nitrate-nitrogen and ammonium-nitrogen concentrations were determined following the instructions in the Hungarian standard, MSZ 20135:1999 (SIMON et al., 2011a, 2011b). The macro- and microelement concentrations in mixed, thoroughly washed, dried and ground willow and black locust plant samples were determined with the ICP-OES technique after $\mathrm{HNO}_{3} / \mathrm{H}_{2} \mathrm{O}_{2}$ digestion in a microwave oven. The nitrogen concentration of the samples was determined using the modified Kjeldahl method (SIMON et al., 2011a, b; 2013a). All measurements were done in 3 replications.

\section{Statistics}

The data were analysed with SPSS 18.0 software using analysis of variance (ANOVA) followed by treatment comparison using Tukey's b-test.

\section{Results and Discussion}

Table 1 shows the effects of the AN, MBC, MSSC, RT, WA and combined treatments on the macro and essential microelement concentrations in the willow leaves, twelve weeks after treatment. The nitrogen concentration in the leaves was 9.8-23.5\% higher than the control in all the treatments, except WA. The most pronounced effect was observed in the MBC, AN+RT and MSSC+WA treatments, but the differences were not significant. The highest nitrogen concentration (3.52 $\mathrm{m} / \mathrm{m} \%$ ) was detected in the MBC treatment, and the lowest $(2.83 \mathrm{~m} / \mathrm{m} \%)$ in the WA and control treatments (Table 1). 
Table 1

Effect of ammonium nitrate (AN), municipal biocompost (MBC), municipal sewage sludge compost (MSSC), rhyolite tuff (RT) and willow ash (WA) on the uptake of macro and essential microelements in the leaves of energy willow (Salix triandra x Salix viminalis cv. Inger) 12 weeks after treatment (field experiment, Nyíregyháza, Hungary, September 2011).

\begin{tabular}{|l|c|c|c|c|c|c|c|c|c|}
\hline \multirow{2}{*}{ Treatments } & $\mathrm{N}$ & $\mathrm{P}$ & $\mathrm{K}$ & $\mathrm{Ca}$ & $\mathrm{Mg}$ & $\mathrm{Fe}$ & $\mathrm{Cu}$ & $\mathrm{Mn}$ & $\mathrm{Zn}$ \\
\cline { 2 - 11 } & $\mathrm{m} / \mathrm{m}^{\mathrm{a}}$ & \multicolumn{3}{|c|}{$\mathrm{mg} \mathrm{g}^{-1}$ dry matter } & \multicolumn{3}{|c|}{$\mu \mathrm{g} \mathrm{g}^{-1}$ dry matter } \\
\hline Control & $2.85^{\mathrm{a}}$ & $5.04^{\mathrm{a}}$ & $11.91^{\mathrm{a}}$ & $10.19^{\mathrm{bc}}$ & $5.18^{\mathrm{a}}$ & $124^{\mathrm{a}}$ & $6.71^{\mathrm{a}}$ & $74.9^{\mathrm{a}}$ & $104^{\mathrm{b}}$ \\
\hline $\begin{array}{l}100 k g h a^{-1} \\
\text { AN }\end{array}$ & $3.33^{\mathrm{a}}$ & $3.20^{\mathrm{ab}}$ & $13.39^{\mathrm{a}}$ & $9.35^{\mathrm{abc}}$ & $4.56^{\mathrm{a}}$ & $103^{\mathrm{a}}$ & $6.87^{\mathrm{a}}$ & $82.6^{\mathrm{a}}$ & $38.3^{\mathrm{ab}}$ \\
\hline $\begin{array}{l}20 t h a^{-1} \\
\text { MBC }\end{array}$ & $3.52^{\mathrm{a}}$ & $3.143^{\mathrm{ab}}$ & $12.70^{\mathrm{a}}$ & $7.35^{\mathrm{a}}$ & $4.37^{\mathrm{a}}$ & $85.7^{\mathrm{a}}$ & $6.48^{\mathrm{a}}$ & $76.7^{\mathrm{a}}$ & $29.4^{\mathrm{a}}$ \\
\hline $\begin{array}{l}15 t h a^{-1} \\
\text { MSSC }\end{array}$ & $3.13^{\mathrm{a}}$ & $3.41^{\mathrm{ab}}$ & $13.70^{\mathrm{a}}$ & $8.66^{\mathrm{ab}}$ & $4.25^{\mathrm{a}}$ & $91.5 \mathrm{a}$ & $6.39^{\mathrm{a}}$ & $73.8^{\mathrm{a}}$ & $37.7^{\mathrm{ab}}$ \\
\hline $\begin{array}{l}30 t h a^{-1} \\
\text { RT }\end{array}$ & $3.23^{\mathrm{a}}$ & $3.93^{\mathrm{a}}$ & $13.39^{\mathrm{a}}$ & $10.28^{\mathrm{bc}}$ & $5.02^{\mathrm{a}}$ & $105^{\mathrm{a}}$ & $7.53^{\mathrm{a}}$ & $99.1^{\mathrm{a}}$ & $58.0^{\mathrm{a}}$ \\
\hline $\begin{array}{l}600 k g h a^{-1} \\
\text { WA }\end{array}$ & $2.83^{\mathrm{a}}$ & $4.03^{\mathrm{ab}}$ & $12.41^{\mathrm{a}}$ & $9.83^{\mathrm{abc}}$ & $4.45^{\mathrm{a}}$ & $107^{\mathrm{a}}$ & $7.34^{\mathrm{a}}$ & $84.5^{\mathrm{a}}$ & $77.9^{\mathrm{a}} \mathrm{b}$ \\
\hline AN+ MBC & $3.13^{\mathrm{a}}$ & $3.537^{\mathrm{ab}}$ & $13.41^{\mathrm{a}}$ & $9.29^{\mathrm{ab}}$ & $4.39^{\mathrm{a}}$ & $86.7^{\mathrm{a}}$ & $7.20^{\mathrm{a}}$ & $70.9^{\mathrm{a}}$ & $28.8^{\mathrm{a}}$ \\
\hline AN+RT & $3.50^{\mathrm{a}}$ & $2.83^{\mathrm{a}}$ & $13.30^{\mathrm{a}}$ & $10.29^{\mathrm{bc}}$ & $4.82^{\mathrm{a}}$ & $85.7^{\mathrm{a}}$ & $7.25^{\mathrm{a}}$ & $96.5^{\mathrm{a}}$ & $29.3^{\mathrm{a}}$ \\
\hline AN+WA & $3.19^{\mathrm{a}}$ & $3.24^{\mathrm{ab}}$ & $13.05^{\mathrm{a}}$ & $9.98^{\mathrm{abc}}$ & $4.58^{\mathrm{a}}$ & $96.6^{\mathrm{a}}$ & $6.46^{\mathrm{a}}$ & $98.0^{\mathrm{ab}}$ & $46.9^{\mathrm{ab}}$ \\
\hline MSSC + WA & $3.50^{\mathrm{a}}$ & $2.82^{\mathrm{b}}$ & $14.13^{\mathrm{a}}$ & $12.13^{\mathrm{c}}$ & $5.03^{\mathrm{a}}$ & $99.0^{\mathrm{a}}$ & $11.6^{\mathrm{a}}$ & $126^{\mathrm{b}}$ & $33.6^{\mathrm{a}}$ \\
\hline
\end{tabular}

Data are the means of 3 replications. ANOVA, Tukey's b-test: means within columns followed by the same letter are not significant at $\mathrm{P}<0.05$.

All the treatments slightly enhanced the potassium content of the leaves, while the magnesium concentration was lower than in the control, but none of these changes in $\mathrm{K}$ and $\mathrm{Mg}$ concentrations proved to be significant (Table 1).

Most of the treatments lowered the uptake of $\mathrm{P}, \mathrm{Mg}, \mathrm{Ca}, \mathrm{Fe}$ and $\mathrm{Zn}$ in the leaves. This can be explained by the stimulation of the aboveground biomass production of energy willow by most of the treatments (Table 2). Since more shoot biomass was formed, the accumulated macro- and microelements were 'diluted' in the organic matrix. The highest $\mathrm{K}, \mathrm{Ca}, \mathrm{Cu}$ and $\mathrm{Mn}$ concentrations were observed in the MSSC+WA treatment.

The soil treatments did not significantly influence the accumulation of toxic elements (As, $\mathrm{Cd}, \mathrm{Pb}$ ) in willow leaves (SIMON et al., 2013a). The lowest As content $\left(0.66 \pm 0.10 \mu \mathrm{g} \mathrm{g}^{-1}\right)$ was found in the $\mathrm{AN}+\mathrm{MBC}$ treatment and the highest $\left(2.11 \pm 0.14 \mu \mathrm{g} \mathrm{g}^{-1}\right)$ in the AN+WA treatment, while $1.66 \pm 0.50 \mu \mathrm{g} \mathrm{g}^{-1}$ As was measured in the control leaves. The As concentration in the basic brown forest soil before soil treatment was relatively high: $38.3 \pm 5.5 \mathrm{mg} \mathrm{kg}^{-1}$ (SIMON et al., 2013a). The highest $\mathrm{Cd}$ concentration $\left(0.99 \pm 0.35 \mu \mathrm{g} \mathrm{g}^{-1}\right)$ was detected in the control leaves, while all the treatments resulted in lower $\mathrm{Cd}$ accumulation. A detectable quantity of $\mathrm{Pb}\left(0.44 \pm 0.06 \mu \mathrm{g} \mathrm{g}^{-1}\right)$ was only present in the AN+WA treatment (SIMON et al., 2013a). 
Table 2 presents the growth parameters of willow 18 months after the soil treatments and 6 months after the second application of ammonium nitrate.

The average number of plants in each plot was 40, regardless of the treatment (data not shown). The AN, MBC, MSSC, RT, AN+MBC and AN+RT treatments significantly enhanced the shoot diameter, at heights of both $50 \mathrm{~cm}$ and $100 \mathrm{~cm}$. This increment was $12.5 \%, 15.7 \%, 16.7 \%, 13.9 \%, 8.3 \%$ and $11.1 \%$ in the AN, MBC, MSSC, RT, AN+MBC and AN+RT treatments at $50 \mathrm{~cm}$ and $14.1 \%, 17.2 \%$, $17.7 \%, 14.6 \%, 10.4 \%$ and $11.5 \%$ at $100 \mathrm{~cm}$ (Table 2).

The total number of shoots produced by the 40 plants in each plot fluctuated from 87 to 119 , with the highest number in the control. All the treatments resulted in the formation of fewer shoots than in the control, but this reduction was not significant (Table 2).

Table 2

Impact of ammonium nitrate (AN), municipal biocompost (MBC), municipal sewage sludge compost (MSSC), rhyolite tuff (RT) and willow ash (WA) soil treatments on the growth parameters of energy willow (Salix triandra x Salix viminalis cv. Inger) (field experiment, Nyíregyháza, Hungary, December 2012 - January 2013; soil application of amendments: June 2011, soil application of ammonium nitrate: June 2011 and June 2012).

\begin{tabular}{|c|c|c|c|c|c|}
\hline Treatments & $\begin{array}{c}\text { Average } \\
\text { diameter } \\
(\mathrm{mm}) \text { of } \\
\text { shoots at } 50 \\
\mathrm{~cm} \text { height } \\
(\mathrm{n}=80 \\
\text { plants/treatment) }\end{array}$ & $\begin{array}{c}\text { Average } \\
\text { diameter }(\mathrm{mm}) \\
\text { of shoots at } 100 \\
\mathrm{~cm} \text { height } \\
(\mathrm{n}=80 \\
\text { plants/treatment })\end{array}$ & $\begin{array}{c}\text { Number of } \\
\text { shoots/40 } \\
\text { plants } \\
\text { ( } \mathrm{n}=40 \\
\text { plants/treatment) }\end{array}$ & $\begin{array}{l}\text { Average } \\
\text { maximum } \\
\text { length } \\
(\mathrm{cm}) \text { of } \\
\text { shoots } \\
\text { (n=48 plants } \\
\text { /treatment) }\end{array}$ & $\begin{array}{c}\text { Average } \\
\text { total } \\
\text { fresh weight } \\
(\mathrm{kg}) \\
\text { of } \\
\text { shoots/plot } \\
(\mathrm{n}=16 \\
\text { rows/treatment })\end{array}$ \\
\hline Control & $21.6^{\mathrm{a}}$ & $19.2^{\mathrm{ab}}$ & $119^{\mathrm{b}}$ & $460^{\mathrm{a}}$ & $51.7^{\mathrm{ab}}$ \\
\hline $\begin{array}{l}100 k g h a^{-1} \\
\text { AN }\end{array}$ & $24.3^{\text {bcde }}$ & $21.9^{\mathrm{cd}}$ & $103^{a b}$ & $481^{\mathrm{abc}}$ & $66.5^{\mathrm{bc}}$ \\
\hline $\begin{array}{l}20 t h a^{-1} \\
\text { MBC }\end{array}$ & $25.0^{\mathrm{de}}$ & $22.5^{\mathrm{d}}$ & $97^{\mathrm{ab}}$ & $506^{\mathrm{d}}$ & $72.9^{c}$ \\
\hline $\begin{array}{l}15 t h a^{-1} \\
\text { MSSC }\end{array}$ & $25.2^{\mathrm{e}}$ & $22.6^{\mathrm{d}}$ & $110^{\mathrm{ab}}$ & $509^{d}$ & $69.5^{c}$ \\
\hline $\begin{array}{l}30 t h a^{-1} \\
\text { RT }\end{array}$ & $24.6^{\text {cde }}$ & $22.0^{\mathrm{cd}}$ & $100^{\mathrm{ab}}$ & $494^{\mathrm{cd}}$ & $64.9^{\mathrm{bc}}$ \\
\hline $\begin{array}{l}600 \mathrm{~kg} \mathrm{ha}^{-1} \\
\text { WA }\end{array}$ & $22.8^{\mathrm{ab}}$ & $20.4^{\mathrm{abc}}$ & $98^{\mathrm{ab}}$ & $487^{\mathrm{bcd}}$ & $60.6^{\mathrm{abc}}$ \\
\hline $\mathrm{AN}+\mathrm{MBC}$ & $23.4^{\mathrm{bcd}}$ & $21.2^{\mathrm{cd}}$ & $113^{\mathrm{ab}}$ & $500^{\mathrm{cd}}$ & $66.0^{\mathrm{bc}}$ \\
\hline $\mathrm{AN}+\mathrm{RT}$ & $24.0^{\text {bcde }}$ & $21.4^{\mathrm{cd}}$ & $96^{\mathrm{ab}}$ & $497^{\mathrm{cd}}$ & $64.4^{\mathrm{bc}}$ \\
\hline $\mathrm{AN}+\mathrm{WA}$ & $23.0^{\mathrm{abc}}$ & $20.6^{\mathrm{bc}}$ & $87^{\mathrm{a}}$ & $481^{\mathrm{abc}}$ & $59.2^{\mathrm{abc}}$ \\
\hline $\mathrm{MSSC}+\mathrm{WA}$ & $21.6^{\mathrm{a}}$ & $18.9^{\mathrm{a}}$ & $92^{\mathrm{ab}}$ & $465^{\mathrm{ab}}$ & $47.9^{\mathrm{a}}$ \\
\hline
\end{tabular}

ANOVA, Tukey's b-test: means within columns followed by the same letter are not significant at $\mathrm{P}<0.05$. 
The shoot length was the greatest in the MBC $(506 \mathrm{~cm})$ and $\operatorname{MSSC}(509 \mathrm{~cm})$ treatments, which was $10 \%$ and $10.7 \%$ more than in the control $(460 \mathrm{~cm})$. All the treatments except $\mathrm{AN}+\mathrm{WA}$ and $\mathrm{MSSC}+\mathrm{WA}$ significantly enhanced the maximum length of shoots as compared to the control (Table 2).

All the treatments except MSSC+WA enhanced the average total fresh weight $(\mathrm{kg})$ of harvested shoots per plot by $14.5-41.1 \%$, compared to the control. This increment was significant for the MBC $(+41.1 \%)$ and MSSC $(+34.4 \%)$ treatments (Table 2). A moderate dose of MSSC stimulated the growth of maize in a former field experiment (SIMON \& SZENTE, 2000). This was confirmed in willow in the present study.

The moisture content of willow shoots was found to vary from 47.06-49.41\% at harvest in January 2013 (50.59-52.94\% dry matter content), regardless of the treatment (SIMON et al., 2013b).

Figure 1 shows the effect of $\mathrm{AN}$ and $\mathrm{AN}-\mathrm{CMC}$ application on the nitratenitrogen concentration of the soil under black locust.

Both fertilizers increased the nitrate-nitrogen content of the upper soil three to four times, with values of $12.51 \mathrm{mg} \mathrm{kg}^{-1}$ and $15.38 \mathrm{mg} \mathrm{kg}^{-1}$ in the $\mathrm{AN}$ and $\mathrm{AN}$ CMC treatments, compared with $3.53 \mathrm{mg} \mathrm{kg}^{-1}$ in the control. At the end of the vegetation period (in December) the nitrate concentration in the soil of the treated plots was similar to that in the control plots (Figure 1).

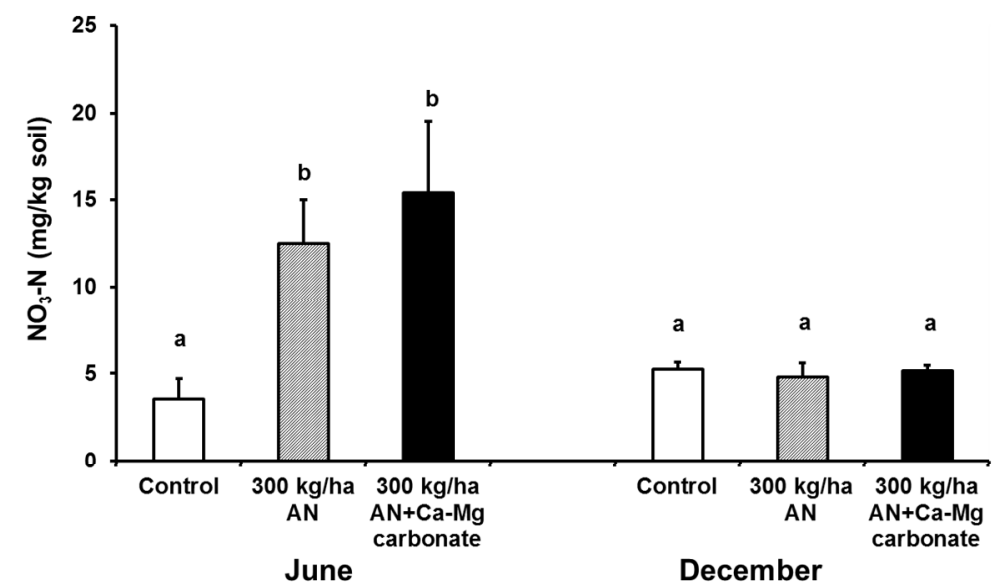

Figure 1

Nitrate-nitrogen content in the soil $(0-25 \mathrm{~cm})$ of 2-year-old black locust (Robinia pseudoacacia L.) after ammonium nitrate (AN) or ammonium nitrate+calcium-magnesium carbonate application (June 2009), and 6 months later (December 2009) (field experiment, Nyíregyháza, Hungary). ANOVA, Tukey's b-test: means within columns followed by the same letter are not significant at $\mathrm{P}<0.05,(\mathrm{n}=3)$ 
The treatments did not significantly influence the total nitrogen content of the upper soil, which was $0.075-0.086 \mathrm{~m} / \mathrm{m} \%$ immediately after soil fertilization and $0.075-0.081 \mathrm{~m} / \mathrm{m} \%$ at the end of the vegetation period (SIMON et al., 2011b). The ammonium-nitrogen content of the soil was 4.91-6.11 mg kg-1 in June, and 5.93$6.52 \mathrm{mg} \mathrm{kg}^{-1}$ in December, so fertilization had no significant effect (SIMON et al., 2011b).

Table 3 demonstrates the effect of nitrogen fertilizer on the macro- and microelement composition of 2-year-old black locust leaf stalks and leaves, 15 weeks after soil treatment. It was supposed that black locust plants assimilated the excess of nitrate-nitrogen from the soil.

The nitrogen concentration ranged from $1.35-1.50 \mathrm{~m} / \mathrm{m} \%$ in the leaf stalks and $2.16-2.50 \mathrm{~m} / \mathrm{m} \%$ in the leaves (Table 3). In a lysimeter experiment performed by MANTOVANI et al. (2015) the average leaf nitrogen content of black locust varied between $2.8 \%$ and $3.0 \%$ when the soil nitrogen content was $0.6-0.9 \mathrm{~g} \mathrm{~N} \mathrm{~kg}^{-1}$.

The nitrogen content of the leaf stalks (petioles) and leaves was only slightly higher in the treated plants; the differences were not significant. Since even a single application of AN or AN-CMC fertilizer enhanced the harvested fresh shoot yield of 3-year-old black locust by 32\% or 19\% (SIMON et al., 2011b), it can be supposed that the absolute (total) nitrogen uptake of treated plants was higher than that of the control.

\section{Table 3}

Effect of ammonium nitrate (AN) and ammonium nitrate with calcium-magnesium carbonate (AN-CMC) fertilizers on the uptake of macro and essential microelements in the leaf stalks and leaves of 5-year-old black locust (Robinia pseudoacacia L.) 15 weeks after soil treatment (field experiment, Nyíregyháza Hungary, October 2009).

\begin{tabular}{|c|c|c|c|c|c|c|c|c|}
\hline \multirow{2}{*}{ Treatments } & $\mathrm{N}$ & $\mathrm{P}$ & $\mathrm{K}$ & $\mathrm{Ca}$ & $\mathrm{Mg}$ & $\mathrm{Cu}$ & $\mathrm{Mn}$ & $\mathrm{Zn}$ \\
\hline & $\mathrm{m} / \mathrm{m} \%$ & \multicolumn{4}{|c|}{$\mathrm{mg} \mathrm{g}^{-1}$} & \multicolumn{3}{|c|}{$\mu \mathrm{g} \mathrm{g}^{-1}$} \\
\hline & \multicolumn{8}{|c|}{ Leaf stalks (petioles) } \\
\hline \multirow{3}{*}{$\begin{array}{l}\text { Control } \\
300 \mathrm{~kg} \mathrm{ha}^{-1} \\
\text { AN } \\
300 \mathrm{~kg} \mathrm{ha}^{-1} \\
\text { AN-CMC }\end{array}$} & $1.37^{\mathrm{a}}$ & $1.528^{\mathrm{a}}$ & $7.608^{\mathrm{a}}$ & $12.915^{\mathrm{a}}$ & $1.561^{\mathrm{a}}$ & $5.79^{a}$ & $9.54^{\mathrm{a}}$ & $21.4^{\mathrm{a}}$ \\
\hline & $1.50^{\mathrm{a}}$ & $1.837^{\mathrm{a}}$ & $7.567^{\mathrm{a}}$ & $9.830^{\mathrm{a}}$ & $1.727^{\mathrm{a}}$ & $5.56^{\mathrm{a}}$ & $8.94^{\mathrm{a}}$ & $20.2^{\mathrm{a}}$ \\
\hline & $1.40^{\mathrm{a}}$ & $1.899^{\mathrm{a}}$ & $6.444^{\mathrm{a}}$ & $11.921^{\mathrm{a}}$ & $1.582^{\mathrm{a}}$ & $6.04^{\mathrm{a}}$ & $9.71^{\mathrm{a}}$ & $21.0^{\mathrm{a}}$ \\
\hline \multirow{4}{*}{$\begin{array}{l}\text { Control } \\
300 \mathrm{~kg} \mathrm{ha}^{-1} \\
\text { AN } \\
300 \mathrm{~kg} \mathrm{ha}^{-1} \\
\text { AN-CMC }\end{array}$} & \multicolumn{8}{|c|}{ Leaf } \\
\hline & $2.16^{\mathrm{a}}$ & $1.658^{\mathrm{a}}$ & $5.510^{\mathrm{a}}$ & $28.643^{a}$ & $3.918^{\mathrm{a}}$ & $5.13^{\mathrm{a}}$ & $36.65^{\mathrm{a}}$ & $27.5^{\mathrm{a}}$ \\
\hline & $2.17^{\mathrm{a}}$ & $1.898^{\mathrm{a}}$ & $6.695^{\mathrm{a}}$ & $25.625^{\mathrm{a}}$ & $3.442^{\mathrm{a}}$ & $5.07^{\mathrm{a}}$ & $30.69^{\mathrm{a}}$ & $27.5^{\mathrm{a}}$ \\
\hline & $2.25^{\mathrm{a}}$ & $1.985^{\mathrm{a}}$ & $7.090^{\mathrm{a}}$ & $27.136^{\mathrm{a}}$ & $4.154^{\mathrm{a}}$ & $5.17^{\mathrm{a}}$ & $38.61^{\mathrm{a}}$ & $24.4^{\mathrm{a}}$ \\
\hline
\end{tabular}

Data are the means of 4 replications. ANOVA, Tukey's b-test: means within columns followed by the same letter are not significant at $\mathrm{P}<0.05$. 
Fertilization slightly increased the phosphorus but reduced the calcium uptake in the leaf stalks and leaves, while the magnesium concentration was not consistently influenced. However, these changes were not significant. The uptake of essential microelements $(\mathrm{Cu}, \mathrm{Mn}, \mathrm{Zn})$ was not significantly influenced by the treatments (Table 3). In the leaves significantly more $\mathrm{N}, \mathrm{Ca}, \mathrm{Mg}$ and $\mathrm{Mn}$ was detected than in the leaf stalks (Table 3). The toxic $\mathrm{Cd}$ and $\mathrm{Pb}$ concentration of the leaves was very low, and was not influenced by the treatments (SIMON et al., 2011b).

In March 2012 when 5-year-old black locust plants fertilized three times (in 2009, 2010, and 2011) were felled, their maximum average length $(n=30)$ was 691 $\mathrm{cm}, 673 \mathrm{~cm}$ and $714 \mathrm{~cm}$ in the control, AN and AN-CMC treatments, respectively.

Figure 2 demonstrates the effect of three doses of nitrogen fertilization on the total fresh shoot yield of 5-year-old black locust. It is clear from the data that the repeated application of AN or AN-CMC fertilizer enhanced the fresh (defoliated) shoot yield of 5 -year-old black locust by $22 \%$ and $28 \%$, respectively. In the case of AN-CMC fertilization, the increment was significant compared to the control.

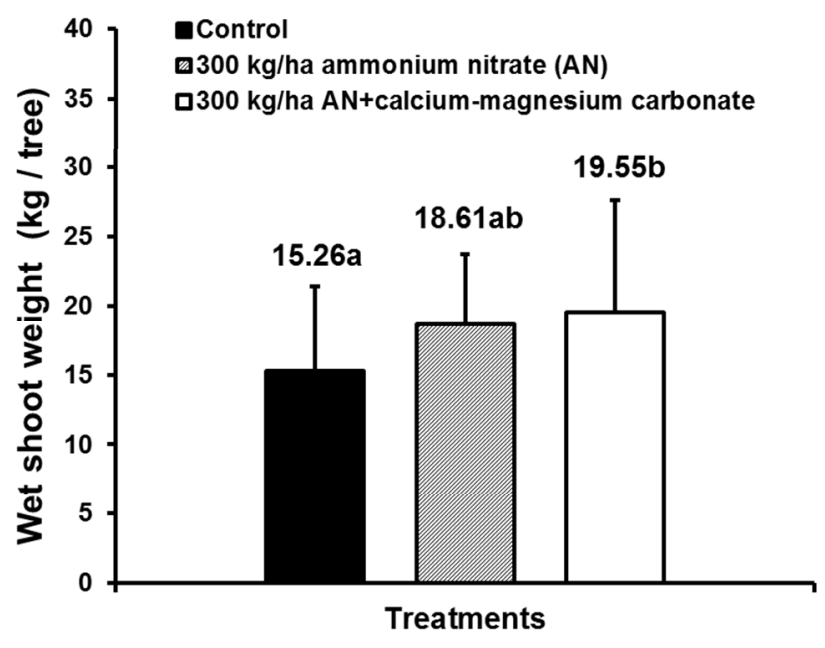

Figure 2

Effect of three applications of nitrogen fertilizer $(2009,2010,2011)$ on the fresh shoot yield of 5-year-old black locust (Robinia pseudoacacia L.) (field experiment, Nyíregyháza,

Hungary, March 2012). ANOVA, Tukey's b-test: means within columns followed by the same letter are not significant at $\mathrm{P}<0.05(\mathrm{n}=30)$.

The average moisture content of harvested shoots from the control, AN and AN-CMC treatment was $34.09 \%, 34.09 \%$ and $33.46 \%$, respectively. The calculated dry shoot yield of black locust in the 5th year was $67.04 t h a^{-1}$ in the control, and $82.55 t h a^{-1}$ and $85.92 t h a^{-1}$ in the AN and AN-CMC treatments, respectively. On an annual basis these values were $16.76 t h a^{-1}, 20.64 t h a^{-1}$, and $21.48 t h a^{-1}$ 
respectively, which were higher than those reported by RÉDEI \& VEPERDI (2009), who found that the increment in the oven-dry dendromass of black locust energy plantations ranged from 6 to $12 t h a^{-1}$ annually.

\section{Conclusions}

Nineteen months after soil treatments the macro- and microelement-rich soil amendments (MBC, MSSC) significantly enhanced the harvested shoot yield of willow plants (up to $41 \%$ ). In spite of the high macro- and microelement content, the combined application of MSSC and WA had a less favourable effect on the harvestable fresh shoot yield of willow. Most of the treatments enhanced the uptake of $\mathrm{N}(9.8-23.5 \%)$ and $\mathrm{K}$ in willow leaves, but the concentrations of $\mathrm{P}, \mathrm{Mg}, \mathrm{Ca}$ and $\mathrm{Fe}$ in the leaves was slightly reduced compared to the control. The accumulation of toxic elements (As, $\mathrm{Cd}, \mathrm{Pb}$ ) in willow leaves from the applied fertilizers or amendments was negligible.

Nitrogen is the most limiting element for plant growth in many ecosystems, despite being the most plentiful element in the atmosphere. In its most abundant form, gaseous dinitrogen $\left(\mathrm{N}_{2}\right)$, nitrogen is unavailable to most organisms. However, following transformation to other forms, especially nitrate $\left(\mathrm{NO}_{3}^{-}\right)$and ammonium $\left(\mathrm{NH}_{4}{ }^{+}\right)$, nitrogen becomes highly reactive in the biosphere and may be highly mobile in water and air, threatening human health (INSTITUTE OF MEDICINE AND NAtional Research Council, 2015). Considering the high fossil fuel (natural gas) costs of producing chemical nitrogen fertilizers (e.g. ammonium nitrate), the loss of nitrogen by leaching or volatilization and the emission of greenhouse gases, the regular application of ammonium nitrate or other nitrogen fertilizers in SRC cultures is questionable from the environmental point of view.

Comparing the impacts of artificial fertilizer (AN) and various soil amendments it can be concluded that biowastes (such as MBC or MSSC) may significantly enhance the growth parameters (shoot diameter, maximum shoot length) and harvestable total weight of willow shoots compared to the control. Since biowastes proved to be as effective in enhancing the yield of SRC willow as ammonium nitrate, their application is highly recommended from the environmental point of view.

In black locust plantations both nitrogen fertilizers (AN, AN-CMC) caused a three to four times increase in the nitrate concentration of the upper soil at the beginning of the vegetation period. Since the excess nitrate disappeared from the upper soil by the end of the vegetation period, it can be assumed that it was either leached from the upper soil to the lower layers or the groundwater or volatilized to the air, or was assimilated by plant roots or shoots. The nitrogen concentration of the leaf stalks (petioles) and leaves, however, was only slightly enhanced during the vegetation period in the treated plants.

Four years after planting and three years after the first nitrogen fertilization, when whole defoliated 5-year-old trees were harvested, $22 \%$ and $28 \%$ higher aboveground fresh weight was detected in the AN or AN-CMC treatments than in 
the control. It is thus clear that black locust responded with yield increments to the good nitrogen supply in the soil, in spite of its well-documented capability of assimilating an annual 30 to $56 \mathrm{~kg} \mathrm{ha}^{-1}$ gaseous dinitrogen from the air through Rhizobia root symbionts (VAN SAMBEEK et al., 2008). The application of AN or AN-CMC mineral fertilizers is not recommended, however, in SRC Robinia stands, due to their unfavourable energy balance (PATZEK \& PIMENTEL, 2005) and to the detrimental effects of reactive nitrogen forms (nitrate $-\mathrm{NO}_{3}{ }^{-}$or ammonium $\mathrm{NH}_{4}{ }^{+}$), which is a threat to human health, degrades air and water quality, and causes stress to terrestrial and aquatic organisms.

SRC energy plantations have a more beneficial effect on the soil and environment when grown on marginal lands than when grown on cropland or natural forests. Their cultivation is therefore recommended in nutrient-depleted, compacted, poorly drained, acidic and eroded soils (BLANCO-CANQUI, 2010). Based on the present results, the nutrient demands of SRC willow or black locust plantations should be met from biowastes such as MBC or MSSC, or from mineral amendments such as RT or WA, rather than from chemical fertilizers such as AN or AN-CMC.

\section{Acknowledgements}

This research was financially supported by Nitrogénmüvek Vegyipari Co. (Pétfürdő, Hungary), who also provided the ammonium nitrate and ammonium nitrate + calcium-magnesium carbonate (trade name 'Pétisó'). The municipal biocompost was produced and provided by Térségi Hulladék-Gazdálkodási Ltd. in Nyíregyháza, Hungary, the municipal sewage sludge compost by Nyírségvíz Ltd., Nyíregyháza, Hungary and rhyolite tuff by Colas-Északkő Bányászati Ltd., Tarcal, Hungary. The licence holder of the willow species is Lantmännen Agroenergi AB, Sweden (Hungarian distributor Holland-Alma Ltd., Piricse). The black locust saplings were provided by Holland-Alma Ltd., Piricse, Hungary.

\section{References}

BLANCO-CANQUI, H. 2010. Energy crops and their implications on soil and environment. Agron. J. 102. 403-419.

BLASKÓ, L., 2008. Cultivation of energy plants, site suitability, availability. In: Renewable Agriculture. (ed.: CHLEPKÓ, T.). 167-207. Magyar Katolikus Rádió. Budapest. (in Hungarian).

BRINKS, J., LHOTKA, J., BARTON, C. 2011. One-year response of American sycamore (Platanus occidentalis L.) and black locust (Robinia pseudoacacia L.) to granular fertilizer applications on a reclaimed surface mine in Eastern Kentucky. In: Proceedings of the 17th Central Hardwood Forest Conference. April 5-7 2010; Lexington, KY. (eds.: FEI, S., et al.). 306-313. Gen. Tech. Rep. NRS-P-78. U.S. Department of Agriculture, Forest Service, Northern Research Station. Newtown Square, PA. https://www.nrs.fs.fed.us/pubs/gtr/gtr-p-78papers/32brinksp78.pdf (May 2018) 
Dimitriou, I. Eriksson, J., Adlerac, A., Aronsson, P., VerwiJst, T., 2006. Fate of heavy metals after application of sewage sludge and wood-ash mixtures to short-rotation willow coppice. Environ. Pollut. 142. (1) 160-169.

GYURICZA, C. 2011. Cultivation of woody energy crops (5.). Plant nutrition in energy plantations. Agrofórum. March 2011. 92-96. (in Hungarian).

Gyuricza, C., Nagy, L., Uju, A., Mikó, P., AleXA, L., 2008. The impact of composts on the heavy metal content of the soil and plants in energy willow plantations (Salix sp.). Cereal Res. Commun. 36. (Supplement 5) 279-282.

HARTA I., GULYÁS M., FÜLEKY G. 2016. Effect of long-term fertilization in a black locust plantation. Agrokém. Talajt. 65. (1) 31-45. (in Hungarian)

Institute OF MEDICINE AND NATIONAL RESEARCH COUNCIL 2015. A Framework for Assessing Effects of the Food System. Annex 4. Nitrogen in Agroecosystems. (eds.: NesheIM, M.C., ORIA M., YIH P.T.) The National Academies Press. Washington DC.

KANZLER, M., BÖHM, C., FREESE D., 2015. Impact of P fertilisation on the growth performance of black locust (Robinia pseudoacacia L.) in a lignite postmining area in Germany. Ann. For. Res. 58. (1) 39-54.

Mantovani, D., Veste, M., Boldt-Burisch, K., Fritsch, S., Koning, L.A., FREESE, D., 2015. Carbon allocation, nodulation, and biological nitrogen fixation of black locust (Robinia pseudoacacia L.) under soil water limitation. Ann. For. Res. 58. (2) 1-16.

Nicolescu, V-R., Hernea, C., BAKti, B., Keserü, Z., Antal, B., RÉDEI, K., 2018. Black locust (Robinia pseudoacacia L.) as a multi-purpose tree species in Hungary and Romania: a review. J. For. Res. https://doi.org/10.1007/s11676018-0626-5 (published online 19 March 2018).

PARK, B.B. YANAI, R.D., SAHM, J.M. , BALlARD, B.D., ABRAHAMSON, L.P., 2005. Wood ash effects on plant and soil in a willow bioenergy plantation. Biomass Bioenergy. 28. (4) 355-365.

PATZEK, T.W., PIMENTEL, D. 2005. Thermodynamics of energy production from biomass. Crit. Rev. Plant Sci. 24. (5-6) 327-364.

PLASS, W. T., 1972. Fertilization treatments increase black locust growth on extremly acid surface-mine spoils. Tree Planters' Notes. 23. (3) 10-12.

RÉDEI, K. \& KESERÜ, Z. 2008. Promising white poplar (Populus alba L.) clones in sandy ridges between the rivers Danube and Tisza in Hungary. Int. J. Horticult. Sci. 14. (1-2) 113-116

RÉDEI, K. \& VEPERDI, I. 2009. The role of black locust (Robinia pseudoacacia L.) in establishment of short-rotation energy plantations in Hungary. Int. J. Horticult. Sci. 15 (3) 41-44.

SEVEl, L., Nord-LARSEN, T., IngERSLEV, M., JøRGENSEN, U., RAULUNDRASMUSSEN, K., 2014a. Fertilization of SRC willow, I: Biomass production response. Bioenerg. Res. 7. 319-328.

Sevel, L., Ingerslev, M., Nord-Larsen, T., Jørgensen, U., Holm, P.E., SCHELDE, K., RAULUND-RASMUSSEN, K., 2014b. Fertilization of SRC willow, II: Leaching and element balances. Bioenerg. Res. 7. 338-352. 
Simon L., SZABó B., SZABÓ M., VARGa C., VinCZE G., 2011a. Investigation of the yield and mineral nutrient supply of energy crops with special attention to combined application of nitrogen fertilizers and biosolids. Innovation research report prepared for Nitrogénművek Vegyipari Co (Pétfürdő, Hungary). College of Nyíregyháza. Technical and Agricultural Faculty. Nyíregyháza. Hungary. 1-91. (in Hungarian).

Simon L., Szabó B., Kalmárné Vass E., Vincze G., Varga C., Barna S., KonCZ J., 2011b. Experiences of nitrogen fertilization in black locust energy plantation. In: Proc. $7^{\text {th }}$ Carpathian Basin Environmental Science Conference, Vol. 1. Cluj-Napoca, Romania, March 24-27, 2011. (eds.: MócsY, I., SZACsVaI, K., URÁK, I., Zsigmond, A.R., SZIKSZAI, A.). 145-149. Ábel Publisher. Cluj-Napoca. Romania. (in Hungarian)

Simon, L., Szabó, B., Szabó, M., Vincze, G., Varga, C, Uri, Zs., Koncz, J., 2013a. Effect of various soil amendments on the mineral nutrition of Salix viminalis and Arundo donax energy crops. Eur. Chem. Bull. 2. (1) 18-21.

Simon, L., MAKÁd, M., VinCZe, GY., SZABÓ, B., SZAbó, M., ARANYOS, T., $2013 b$. Impact of ammonium nitrate and rhyolite tuff soil application on the photosynthesis and growth of energy willow. In: International Multidisciplinary Conference. 10th edition. May 22-24, 2013. Baia Mare, Romania - Nyíregyháza, Hungary. (eds.: Ungureanu, N., Cotetiu, R., SiKolya, L., PÁY, G.). 143-146. Scientific Bulletin Serie C. Fascicle: Mechanics, Tribology, Machine Manufacturing Technology. Bessenyei Book Publisher. Nyíregyháza (Hungary).

Simon L. VinCZE G., URi Z., IRINYINÉ Oláh K., VÍGH S., MAKÁdi M., ARANYOS T., ZsOMBIK L., 2016. Long-term field fertilization experiment with energy willow (Salix sp.) - experiences of the first 5 years. Növényterm. 65. (2) 5976. (in Hungarian).

Simon, L. MAKÁdI, M., VinCZe, G., URI, Z., IRINYINÉ OláH, K., ZsombiK, L., VíGH, SZ., SZABÓ, B., 2018. Long-term field fertilization experiment with energy willow (Salix sp.) - Elemental composition and chlorophyll fluorescence in the leaves. Agrokém. Talajt. 67. (1.) 91-104.

SimON, L., SZENTE, K. 2000. Effect of sewage sludge compost on the nitrogen uptake, on several physiological parameters and yield of maize. Agrokém. Talajt. 49. (1-2) 231-246 (in Hungarian)

SMART, B.L. \& CAMERON, K.D., 2012. Shrub willow. In: Handbook of Bioenergy Crop Plants. (eds.: Kole, C., Joshi, C.P. \& SHONnARD, D.R.) 687-708. CRC Press. Boca Raton, London, New York.

StRaKeR, K.C., QUinN, L.D., Voigt, T.B., LeE, D.K., Kling, D.J., 2015. Black locust as a bioenergy feedstock: a review. BioEnergy Res. 8. (3) 1117-1135.

SZABÓ B., SimOn L., MAKÁdi M., VINCZE G., SZABÓ M., 2011. Effect of rhyolite tuff on the yield parameters of maize, sour cherry, energy willow cultures. Innovation research report prepared for Colas-Északkő Bányászati Ltd., (Tarcal, Hungary). College of Nyíregyháza, Technical and Agricultural Faculty. (Nyíregyháza, Hungary). 1-35. (in Hungarian). 
SZABÓ B., SZABÓ M., VARGA C., VÁGVÖLGYI S., SIMON L., 2012. Effect of rhyolite tuff on the growth parameters of energy willow. In: 36th Óvár Scientific Day. Hungarian Agriculture. Possibilities - resources - ideas. Mosonmagyaróvár. Hungary. October 5, 2012. (ed.: KovÁCsNÉ GAÁL, K.). 471-476 (CD proceedings, ISBN 978-963-9883-93-2) (in Hungarian).

VAn SAmbeeK, J.W., NAVARRETe-Tindall, N.E., HunT, K.L., 2008. Growth and foliar nitrogen concentrations of interplanted native woody legumes and pecan. In: Proceedings of the 16th Central Hardwood Forest Conference. 2008 April 8-9; West Lafayette. (eds.: JACOBS, D. F.; MiCHLER, C. H.). 580-588. Gen. Tech. Rep. NRS-P-24. U.S. Department of Agriculture, Forest Service, Northern Research Station. Newtown Square, PA. https://www.nrs.fs.fed.us/pubs/gtr/gtr-p-24\%20papers/63vansambeek-p-24.pdf (May 2018) 